\title{
Ökoloogilised vaatenurgad ja laste internetikasutus: sissevaade mikro- ja makrotasandi analüüsi
}

\author{
Brian O’Neilla1 \\ a Dublini Tehnoloogiainstituut
}

\begin{abstract}
Annotatsioon
Igivanad arutelud, milles käsitletakse laste kokkupuudet meediatehnoloogiaga, toovad kommunikatsiooni ja meediauuringute suunal esile erimeelsusi ja vaidlusi põhjustanud pikaajalise traditsiooni. Olgugi et meediatarbimise mõju lastele on uuritud juba ringhäälingu algusaegadest peale, on selle üle endiselt vähe teoretiseeritud ja seda on kirjanduses harva käsitletud, samuti on see meediapoliitika debattides pälvinud vaid vähest mõistmist. Laste ja internetiuuringute puhul on vanad vaidlused süvenenud. Lähtudes ühelt poolt hoiatavatest teadetest riskide, ülemäärase arvutikasutuse ja selle kahjuliku mõju kohta ning teiselt poolt kiidulaulust „digimaailma päriselanikele” ja tehnoloogia võimele muuta maailma, seadis EU Kids Online endale eesmärgiks koguda andmeid, mis aitavad luua terviklikumat pilti veebikeskkonnast, milles noored tegutsevad. Siinses artiklis paigutan selle valdkonna tööd ökoloogilisse raamistikku, lähtudes nii Bronfenbrenneri bioökoloogilisest käsitlusviisist, mis on olnud tähtsal kohal uutes lapsepõlve sotsioloogilistes käsitlustes, kui ka üldisemalt defineeritud meediaökoloogia teoreetilisest raamistikust. Viimast seostatakse peamiselt McLuhani ja hiljem Postmani töödega, kus kirjeldatakse meediakeskkonda kui keerulise vastastikuse mõjutamise süsteemi tehnoloogia ja ühiskonna vahel, kus mitmesugused suhtlusviisid ja vahendatud vastastikune mõjutamine kujundavad oluliselt inimkäitumist ja ühiskondlikku elu. Selline vaatenurk on mõningate põletavate probleemidega tegelemisel väga vajalik, kui kõne all on teadusuuringutel põhinev poliitikakujundamine, mis on seotud interneti haldamise ja reguleerimisega ning noorte kaitsmisega internetikeskkonnas.
\end{abstract}

Võtmesõnad: lapsed ja internet, meediaökoloogia, riskid internetis, Bronfenbrenner, EU Kids Online

1 Dublini Tehnoloogiainstituut, Grangegorman, Dublin 7, Iirimaa; brian.oneill@dit.ie 


\section{Sissejuhatus}

Kommunikatsiooniuuringute valdkonnas on vähe teemasid, mis kutsuvad esile tulisemaid vaidlusi kui meediakasutuse arvatav mõju laste ja noorte heaolule. Lapsepõlve vaadeldakse harva neutraalselt (Livingstone, Haddon, \& Görzig, 2012) ja veelgi vähem neutraalselt suhtutakse meedia võimalikku mõjusse lastele. Hoolimata selle vaidluse pikaajalisusest ja tohutust hulgast teaduskirjandusest, milles käsitletakse meedia mõju lastele, on siiski tegemist teemaga, mille kohta on vähe teoreetilist materjali ning mis ei ole kuigi hästi esindatud ei peavoolu meedia- ja kommunikatsiooniuuringutes ega arengupsühholoogias. Kõnealune vaidlus on kestnud pikalt ja pidevalt, väljendudes mures (Heins, 2008), mis sai alguse 1920. aastate lõpus ning jätkus pidevate üksteisele järgnevate faasidena, mille käigus uuriti vastavalt meedia suundumustele kino mõju laste füüsilisele ja kognitiivsele arengule (Jowett, Jarvie, \& Fuller, 1996) või analüüsiti psühholoogiliste uuringutega raadio kuulamise mõju noortele inimestele (Cantril \& Allport, 1935). Arutelu kulmineerus 1960ndatel ägedate vaidlustega televisiooni kahjuliku mõju üle seoses selles näidatava vägivalla, täiskasvanute programmide ja reklaamidega (Glucksmann \& Bennett, 1971). Iga etapp on tekitanud moralistide seas paanikat, mida ametnike vaenulikkus on sageli tagant õhutanud. Iga kord on sellele reageeritud teaduslike uuringutega, eelkõige arvukate mõjuuuringutega. Suurem osa sellistest aruteludest on viinud mitmesuguste normatiivsete meetmeteni, mille eesmärk on piirata meedia mõju ja kättesaadavust lastele. Siinkohal väärivad oluliste näidetena äramärkimist Payne'i sihtasutuse uuringud, mis aitasid kaasa Haysi koodeksi vastuvõtmisele 1930. aastate Hollywoodis, Ameerika kaitseväe peaarsti aruande koostamisele reguleerimata televisioonivõrkude haldamiseks 1960. aastate Ameerika Ühendriikides (Surgeon General's Scientific Advisory Committee, 1972), teleritele paigaldatava V-kiibi kasutuselevõtule Clintoni valitsusajal, samuti ebaõnnestunud sündsa suhtlemise seaduse vastuvõtmisele 1996. aastal ja muudele samaväärsetele meetmetele, mille eesmärk oli filtreerida ja salastada meediasisu (Resnick \& Miller, 1996). Kõiki neid tagasihoidlikke samme on ühendanud üldsuse laialdane usaldamatus meedia vastu ja mure, et see võib avaldada lastele negatiivset mõju.

Pealiskaudsel vaatlusel võib tunduda, et laste info- ja kommunikatsioonitehnoloogia (IKT), teatud digitehnoloogia ja internetikasutus võivad sattuda samasse, juba tuttavasse mustrisse, kui ei oleks olukorda tasakaalustavat alternatiivset arutelu, mille käigus ülistatakse võimalusi, mida digitehnoloogia noortele pakub, ning levitatakse utoopilisi väiteid Prensky „digimaailma päriselanike” (2001) kohta. Erinevalt teistest meedia 
arenguvormidest on internetti vähem silmatorkavalt samastatud noortes inimestes olulisi muutusi esilekutsuva tehnoloogiaga, millega kaasneb täiesti uue kirjaoskuse ja suhtlusviisi teke ning mille kasutamine on nende edaspidises elus möödapääsmatu, kui nad tahavad olla produktiivsed ja ühiskonnaelus aktiivselt osalevad täiskasvanud ja kodanikud. Seevastu televisiooni on peaaegu alati käsitletud negatiivses võtmes või kõige paremal juhul kui neutraalset jõudu, mis ei avalda lastele ei head ega halba mõju (Schramm, Lyle, \& Parker, 1961). Samas kohtab varem kasutamata väiteid interneti võimalike negatiivsete mõjude kohta, näiteks kognitiivse arengu kahjustamise või seksuaalse ahistamise või ärakasutamise oht, mida on traditsioonilist meediat käsitlevates „,aruteludes meedia kahjuliku mõju kohta" üliharva mainitud (Gillespie, 2008). Niisiis on laste võime kohaneda digitehnoloogiaga mõlema võistleva poole arutelude ja liialdatud väidete keskpunktiks. Lastes nähakse uue ühiskonda lõhestava tehnoloogia esmaproovijaid ja omaksvõtjaid olukorras, kus täiskasvanutest digitaalse maailma immigrandid ei pruugi neid vahendeid ei mõista ega vääriliselt hinnata (Palfrey \& Gasser, 2010), või leitakse, et noored on lapsepõlvele hukatuslikult mõjuva dehumaniseeriva tehnoloogia abitud ohvrid (American Academy of Pediatrics, 2013; Spitzer, 2012).

Meediatehnoloogiaga seotud kriitiline mõtlemine, mis lähtub keskkondlikust vaatepunktist, tugineb suuresti nn meediaökoloogia traditsioonile (Strate, 2004). Meediaökoloogia on meedia- ja kommunikatsiooniuuringute oluline osa, mis analüüsib, kuidas meediasüsteemid, -vahendid ja -sisu kujundavad ning mõjutavad inimeste taju, arusaamu, tundeid ja väärtushinnanguid. Meediaökoloogia kirjeldab meedia kõikehõlmavat mõju tänapäeva ühiskonnale, kus see tekitab edasiviiva keskkonna, milles luuakse identiteete ning praktiseeritakse mitmesuguseid suhtlus- ja käitumisviise. Meediaökoloogide jaoks on peamiseks küsimuseks, kuidas meediakeskkond mõjutab inimarengut ja kas see mõju on soodne või arengut pärssiv. Eriti oluline on see küsimus seoses laste ja meediaga. Taustaks ammused ja püsivalt päevakorras olnud arutelud meedia mõjust lastele, on laste internetikogemusi ja veebitehnoloogia kasutamist käsitlenud uuring murelikkust veelgi süvendanud. Meediaökoloogilise käsitlusviisi korral ühendatakse kahtlev hoiak laste elu mõjutava tehnoloogia suhtes tõsise huviga meedia negatiivset mõju tasakaalustavate haridusvõimaluste vastu. Seetõttu on arutelud õppimise tuleviku ja interaktiivse meediatehnoloogia rolli üle nii meediaökoloogide jaoks kui ka ökoloogilisest vaatenurgast eriti olulised.

Artiklis käsitlen võimalust kasutada meediaökoloogiat teoreetilise raamistikuna, mis võimaldab rakendada empiirilisi meetodeid laste meediakogemuse uurimiseks. Tuginedes Euroopa laste interneti kasutamise 
võimaluste ja ohtude uuringuprojektile EU Kids Online, sean ökoloogilised käsitlusviisid, eelkõige Bronfenbrenneri bioökoloogilise käsitluse (1994), teoreetiliseks lähtekohaks noorte internetikasutajate ja meediakeskkonna vastastikmõju hindamisel. Bronfenbrenneri bioökoloogilist teooriat kasutatakse laialdaselt lapsepõlve arenguaspektide uurimiseks. Samas pööratakse selles käsitluses paljudele tänapäeva lapsepõlve juurde kuuluvatele tehnoloogilistele suhtlusviisidele suhteliselt vähe tähelepanu. Et hõlmata oma uurimuses ka tehnoloogiliste vahendite vahendusel toimuvat suhtlust, kasutasin üleeuroopalise uurimisvõrgustiku EU Kids Online uuringut, mis keskendus laste kogemustele internetis. EU Kids Online'i uuringu kontseptsiooni (Hasebrink, Livingstone, Haddon, \& Ólafsson, 2009) kohaselt kuulub iga laps kindlasse sotsiaalsesse ja demograafilisse konteksti, kus teda kujundavad mitmesugused rahvuslikul ja rahvusvahelisel tasandil toimivad kultuurilised ja ühiskondlikud tegurid. Lähtudes ühelt poolt hoiatavatest teadetest riskide, ülemäärase arvutikasutuse ja selle kahjuliku mõju kohta ning teiselt poolt kiidulaulust „digimaailma päriselanikele” ja tehnoloogia võimele muuta maailma, seadis EU Kids Online endale eesmärgiks koguda andmeid, mis aitavad luua terviklikumat pilti veebikeskkonnast, milles noored tegutsevad. Minu arvates võimaldab ökoloogiline lähenemine laste veebikogemuste uurimisele kirjeldada meediakeskkonda kui keerulise vastastikuse mõjutamise süsteemi tehnoloogia ja ühiskonna vahel, kus mitmesugused suhtlusviisid ja vahendatud vastastikune mõjutamine kujundavad oluliselt inimkäitumist ja ühiskondlikku elu. Selline vaatenurk on mõningate põletavate probleemidega tegelemisel väga vajalik, kui kõne all on teadusuuringutel põhinev poliitikakujundamine, mis on seotud interneti haldamise, reguleerimise ja noorte kaitsmisega internetikeskkonnas.

\section{Meediaökoloogia}

Kõige enam tuntakse selliseid ökoloogilisi meedia käsitlusviise, mis kuuluvad nn meediaökoloogia traditsiooni (Strate, 2004). See hõlmab PõhjaAmeerika liberaalsest humanistlikust traditsioonist pärinevat mõtteviisi, mida esindavad Eric Havelock, Suzanne Langer, Lewis Mumford ja eelkõige Marshall McLuhan. Selle traditsiooniga tihedalt seostatud meediateoreetiku Neil Postmani arvamuse kohaselt tuleneb meediaökoloogia bioloogilisest metafoorist ning selle raames uuritakse, kuidas kommunikatsioonimeedia mõjutab inimeste taju, seisukohti, tundeid ja väärtushinnanguid ning kas meie suhe meediaga soodustab või vähendab meie ellujäämisvõimalusi (Postman, 2000). Tegemist on keskkonnauuringuga, mis võimaldab analüüsida meedia struktuuri, sisu ja mõju inimestele ning 
käsitleb meediakeskkonda kui keerulist sõnumite süsteemi, mis sunnib inimesi teatud viisil mõtlema, tundma ja käituma. Meediaökoloogide peamine eesmärk on paljastada meediast küllastunud keskkonna varjatud kihistused, uurides, kuidas meedia kujundab ja mõjutab inimeste taju, arusaamu, tundeid ja väärtushinnanguid.

Haridus on olnud nii Postmani kui ka McLuhani ning teiste silmapaistvate meediaökoloogia uurijate jaoks peamine huviobjekt (Ross, 2009). Kuigi Postman (2000) peab õpetamist õõnestavaks tegevuseks, leiab ta, et meedia seab hariduse naeruväärsesse olukorda, ning laidab selle uimastavat mõju. Lähtudes ilmselt konservatiivsest ja reaktsioonilisest vaatenurgast, mis on vastu tänapäeva ühiskonna muutumisele tehnoloogiakeskseks, väidavad Postman ja mõned temaga ühel meelel olevad meediaökoloogid, et ilma kardinaalsete uuendusteta on tehnoloogial õppekavadele vähe kasulikku lisada ja tehnoloogia vaid õõnestaks jõupingutusi, mida tehakse kriitilise mõtlemise stimuleerimise nimel. Huvitaval kombel suhtub McLuhan meediatehnoloogia hariduslikku potentsiaali märksa leebemalt, tunnistades tehnoloogia selget võimet ühendada inimesi ja lammutada osadeks keerulisi kommunikatsioonisüsteeme. McLuhani populaarseks osutunud üleskutse mõjutas kahtlemata tervet haridustöötajate põlvkonda, pannes nad tegelema kriitiliste meediauuringutega ja võtma tundides kasutusele tehnoloogilised vahendid, mis aitavad kaasa loomingulisuse, ettevõtlikkuse ja kriitilise mõtlemise arengule (Bates, 1984; Moody, 1999). Kriitilise kommunikatsiooni teadlane James Carey muutis suhtumist McLuhanisse ja meediaökoloogilisse mõtlemisse, hinnates ümber sellele omistatud reaktsioonilise tehnoloogilise determinismi ning väärtustades meediaökoloogia võimet aidata paremini mõista viise, kuidas ühiskonna osalised võtavad meediatehnoloogia omaks ja kasutavad seda oma igapäevaelus (Carey, 1981; Grosswiler, 2006). Samas säilis kriitiline suhtumine sellesse abstraktsesse käsitlusviisi ja empiiriliste üksikasjade eiramisse, mis ei lasknud paljudel metoodikutel meediale tuginevate edumeelsete õppekavade puhul juhinduda sellel teoorial põhinevatest järeldustest ja soovitustest.

\section{Bioökoloogiline raamistik}

Bronfenbrenneri ja tema kolleegide loodud nn bioökoloogilise käsitlusviisi puhul rakendatakse sotsiaalteaduslikust seisukohast erinevat ökoloogilist käsitlust. Tegemist on olulise ning arengupsühholoogias, pediaatrias ja lapsepõlveuuringutes laialdaselt kasutatud mudeliga, mida tutvustati esimest korda 1970ndatel (Bronfenbrenner, 1979) ja arendati edasi 
järgnevatel aastakümnetel. Selle mudeli kohaselt on inimareng areneva isiku ja tema keskkonna vaheline vastastikuse mõjutamise protsess ning inimarengu mõistmiseks tuleb uurida keskkonda, milles inimesed elavad ja kasvavad. Selle teooria kohaselt koosneb ökoloogiline süsteem mitmest allpool loetletud ühiskondlikult organiseeritud allsüsteemist, mis toetavad inimese kasvamist ja arengut:

1) mikrosüsteem, mis põhineb areneva isiku ja teda vahetult ümbritseva keskkonna suhetel, eelkõige peresisesed suhted;

2) mesosüsteem, mis kujuneb välja suhetest kahe või enama mikrosüsteemi vahel, milles arenev isik aktiivselt osaleb, näiteks lapse osalemine kodu ja kooli vastastikmõjus;

3) eksosüsteem, mis koosneb ühest või enamast keskkonnast, mis ei kaasa arenevat isikut aktiivse osalejana, kuid mis siiski mõjutab teda;

4) makrosüsteem, mis esineb struktuurilise järjepidevuse vormis subkultuuride või kultuurina, millele lisanduvad kogu struktuuri toetavad uskumused ja ideoloogiad;

5) kronosüsteem, mis hõlmab muude allsüsteemide ajaloolist arengut (ibid.). Selliseid kinnistunud ehk pesastunud allsüsteeme kujutatakse sageli kontsentriliste ringidena (joonis 1), mis hõlmavad üha keerulisemaid mõjusfääre, milles toimub areng tänu ümbritseva keskkonna vastastikmõjust saadavale kogemusele (Bronfenbrenner \& Ceci, 1994).

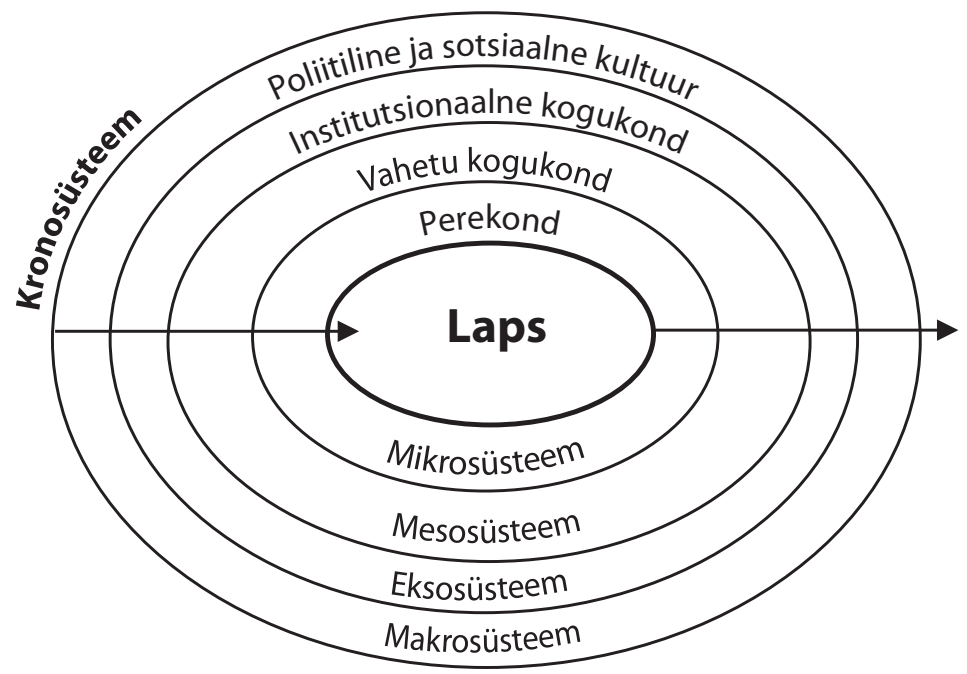

Joonis 1. Bronfenbrenneri ökoloogiline arenguteooria (Halpern \& Figueiras, 2004)

Bronfenbrenner (2005) võtab seda käsitlusviisi selgitava teoreetilise raamistiku kokku kahe peamise teesiga. 
Tees 1. Selleks, et inimene, olgu siis laps või täiskasvanu, saaks areneda - nii intellektuaalselt, emotsionaalselt, sotsiaalselt kui ka moraalselt -, peab ta saama aktiivselt osaleda järjest keerulisemas vastastikuse mõjutamise protsessis koos teiste inimeste, objektide ja sümbolitega, mis paiknevad inimese vahetus keskkonnas. Et vastastikune mõjutamine oleks efektiivne, peab see toimuma üsna korrapäraselt ja pika ajavahemiku jooksul. Sellist vahetus keskkonnas toimuvat regulaarset vastastikust mõjutamist nimetatakse proksimaalprotsessiks. Proksimaalprotsesse peetakse inimarengu peamisteks mootoriteks. Selliste püsivate protsesside näideteks on lapsevanema ja lapse vahelised tegevused, lastevahelised tegevused, rühmas või üksinda mängimine, lugemine, uute teadmiste omandamine, probleemide lahendamine, keeruliste ülesannete täitmine ning uute teadmiste ja oskuste omandamine. Proksimaalprotsessides nähakse mehhanismi, mille kaudu realiseeritakse inimese tegelik psühholoogilise tegutsemise võime (ibid., lk 4).

Tees 2. Proksimaalprotsessid ei saa ennast ise struktureerida, juhtida ega säilitada. Nende vorm, tugevus, sisu ja suund on areneva isiku ning teda ümbritseva vahetu ja kaugema keskkonna, tema elukaart hõlmava aja ja ajaloolise perioodi ning vaatluse all oleva arenguväljundi olemuse koostoime tõttu pidevas muutumises (ibid., lk 4).

Bronfenbrenner väidab raamatus „Inimarengu ökoloogia” (1979), et oma võimetelt näivad inimesed olevat unikaalsed.

... kohaneda, taluda ja eelkõige luua keskkonda, milles ta elab ja kasvab. Selgub, et inimloomus, millest ma kunagi mõtlesin kui ainsuse vormis nimisõnast, on eri kontekstides mitmuslik ja pluralistlik, sest eri keskkonnad ei tekita mitte ainult ühiskondade vahel, vaid ka nende sees tajutavaid erinevusi loomupärastes annetes, temperamendis, inimsuhetes ja eelkõige viisis, kuidas iga kultuur ja subkultuur kasvatavad järgmist põlvkonda. Inimolendist inimese kujundamise protsess ja lõpptulemus on otseses sõltuvuses ajast ja kohast. Vaadeldes seda protsessi ajaloolisest ja kultuuridevahelisest vaatenurgast, viitab seda laadi mitmekülgsus selliste keskkondade võimalikkusele, mida ei ole veel proovitud ja mis kätkevad inimloomuse jaoks enneolematut potentsiaali, milles võib sisalduda senini avaldunust mõistlikum segu jõust ja osavõtlikkusest (ibid., lk xiii). 
Kuigi bioökoloogilisel käsitlusviisil on olnud suur mõju mitmesugustele keskkondadele ja kontekstidele, on meediateadlased sellele siiani võrdlemisi vähe tähelepanu pööranud, hoolimata käsitluse suhtelisest paindlikkusest ning poliitilisest ja haridusalasest huvist meedia kui mõjusa keskkonna vastu. Bronfenbrenner (1979) ei lugenud televisiooni proksimaalprotsessiks, vaid „teisejärguliseks mõjutajaks, mis ei toimi täielikult mikrosüsteemi sees, vaid pigem ökoloogiliste piiride üleselt kui eksosüsteemi nähtus" (lk 242). Ta keskendus peamiselt inimeste vastastikmõjudele ja viitas mõningase halvakspanuga televisioonile kui peaaegu igas kodus leiduvale vidinale, mis segab perekonnaliikmete suhtlust (Bronfenbrenner, 1975). Seevastu Jordan (2004) peab ökoloogilist käsitlusviisi oluliseks just seetõttu, et selle puhul keskendutakse ühtaegu nii üksiku lapse iseloomujoontele, kodusele keskkonnale kui ka teda kõikjal ümbritsevale kultuurikeskkonnale. Toetades ideed, et kodu on multimeediakeskkond, väidab ta, et meedia on olnud alati kodusesse suhtlusesse peenelt põimunud (Jordan, 2004). Atkin ja teised (1991) uurisid kaabeltelevisiooni mõju kodudes, määrates kindlaks kolm selle vahendusel toimuva suhtluse tasandit. Esiteks, koduses mikrosüsteemis mõjutab lapsevanema-lapse vastastikmõju otseselt televiisori vaatamist. Teiseks määrab makrosüsteem kindlaks saadete edastamise viisi, kättesaadavuse ja seadusest tulenevad piirangud. Kolmandaks on televisioonil eksosüsteemi tasandil dünaamiline mõju, mis teisejärgulise tegurina ei jäta puutumata vanemaid ning nende ja laste vastastikmõju, toimides sel viisil ökoloogiliste piiride üleselt. Nad väidavad, et igal tasandil võiks uurida erinevusi vanemlikus vahendamises, lähtudes sellistest makrotasandi eeldustest nagu amet, sissetulek, haridus ja rahvus, ning mikrotasandi mõjutajatest, näiteks vanus, laste arv ja iga ning üksikvanema või mõlema vanemaga perekonnad (Atkin, Greenberg, \& Baldwin, 1991).

Hiljem on Atkin (2001) olnud seisukohal, et kodule keskendunud ökoloogiline vaatenurk on eriti asjakohane sellise põlvkonna puhul, kelle kogemused multimeedia ja mitmesuguse meediatehnoloogiaga pärinevadki üksnes kodunt. „Digimaailma päriselanike” (Prensky, 2001) põlvkonnale on meedia kasutamise ja vastastikuse mõjutamisega seoses antud seega enneolematu valikuvõimalus ja kontroll. See eeldab meediatarbimise osakaalu suurenemist koduses vastastikuses mõjutamises, aga ka seda, et seoses uue meedia mõjuga proksimaalprotsessidele tuleb üha suuremat tähelepanu pöörata arengule meedia eksosüsteemis või keskkonnas (uute meediateenuste ja -tehnoloogiate kasutuselevõtt), samuti suureneb vanemliku vahenduse tähtsus, kui vaja on piirata laste juurdepääsu meediale. Võttes arvesse interneti kui uue keskkonnaga kaasnenud uusi ühiskonda 
lõhestavaid vastastikmõjusid, väidab Atkin, et ökoloogiliste käsitlusviiside ajakohastamisel tuleks arvestada ka pidevalt uuenevate veebirakendustega. Erinevalt passiivsest teleri vaatamisest koduseinte vahel eeldab see keskkond vahendustegevust, mis nõuab suuremat vanemlikku aktiivsust, ning sellega luuakse oluliselt muutunud ja keerulisem eksosüsteemi nähtus, mis esitab vanematele rangemaid nõudmisi ja paneb neile suurema vastutuse meediasisu sissevoolu juhtimisel mikrosüsteemi tasandil. Selline vaieldava väärtusega meediakontekst koos mitmesuguste ühiskondlike nähtustega, mida Bronfenbrenner kirjeldas kui „kasvavat kaost” laste elus (laste ülekaalulisus, düsmorfiline kehapildi tajumise häire, antisotsiaalne käitumine, tähelepanupuudulikkus), sunnib teadlasi viivitamatult uurima keskkonna mõju lapse arengule.

Kuna tehnoloogia muutub üha keerulisemaks ja samas tänapäeva lastele järjest kättesaadavamaks, võttis Johnson kasutusele ökoloogilise tehnoalasüsteemi mõiste, mis tähistab mikrosüsteemi üht mõõdet (joonis 2) ning koosneb peale elusate (nt klassikaaslased) ja elutute (nt riistvara) suhtluspartnerite vastastikmõju ka infost ja meelelahutuslikust tehnoloogiast vahetus ja kaudses keskkonnas (Johnson \& Puplampu, 2008).

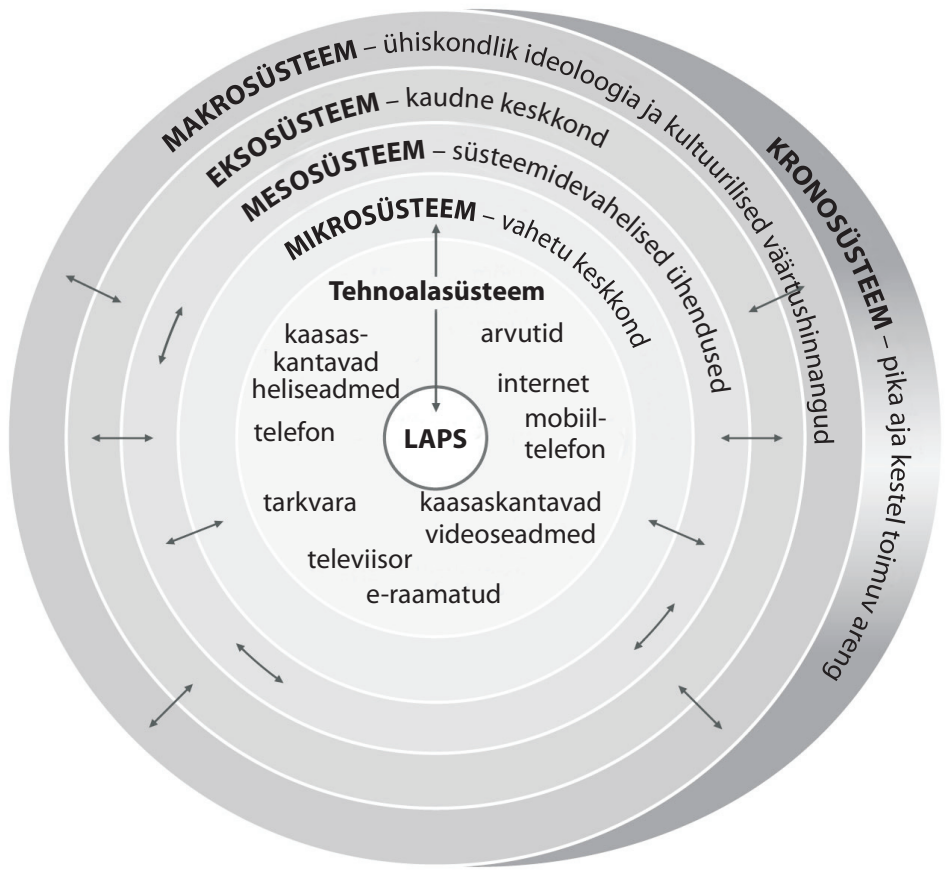

Joonis 2. Ökoloogiline tehnoalasüsteem (Johnson \& Puplampu, 2008) 
Keskendudes ökoloogilisele tehnoalasüsteemile, rõhutavad Johnson ja Puplampu (2008) tehnoloogia osa lapse arengus ning soovitavad uurida lapsepõlveaegse internetikasutuse kogumõju arengule, lähtudes areneva isiksuse ja tema vahetu keskkonna vastastikusest kohanemisest.

\section{EU Kids Online'i uuringu teoreetiline raamistik}

Euroopa laste interneti kasutamise võimaluste ja ohtude uuringuprojekt EU Kids Online ${ }^{2}$ on üleeuroopaline uuringuvõrgustik, mille eesmärk on laiendada teadmisi Euroopa laste internetikasutuse võimaluste, ohtude ja turvalisuse kohta. Lähtudes Euroopa laste meediatarbimise kogemust käsitleva võrdleva uuringu traditsioonist, püütakse mitmesuguste meetodite abil selgitada välja laste ja lapsevanemate internetikasutuse kogemused, et anda realistlik hinnang neid varitsevatele ohtudele ja viisile, kuidas nad sellistele ohtudele reageerivad.

Valmistades ette oma uuringut, mis käsitles laste kogemusi seoses ohtude ja turvalisusega internetitehnoloogia kasutamisel, töötas EU Kids Online'i võrgustik välja toimiva mudeli, mille puhul lähtuti peamiste uurimisküsimuste koostamisel kaudselt bioökoloogilisest käsitlusviisist ning asetati uurimistulemused asjakohasesse tõlgendusraamistikku. Kuna teooriapõhiseid uuringuid, mis puudutavad uue meediatehnoloogia kasutamist laste hulgas, on vähe, pakub Bronfenbrenneri bioökoloogiline raamistik head lähtekohta, et uurida laste internetikogemusi, väljavaateid ja tegevust lapsekesksel viisil ning asetada uurimistulemused struktureeritud ühiskondlike mõjutuste konteksti. Need mõjutused on esitatud perekonda, kogukonda ja kultuuri tähistavate kontsentriliste ringidena (Livingstone et al., 2012). Kõnealune mudel (joonis 3) kirjeldab kolme omavahelises sõltuvuses olevat vastastiksuhete kogumit:

2 EU Kids Online'i võrgustikku rahastab Euroopa Komisjoni turvalisema interneti programm kolmes üksteisele järgnevas etapis ajavahemikus 2006-2014, et suurendada teadmisi laste ja lapsevanemate kogemuste ja praktika kohta seoses internetija uue veebitehnoloogia riskantse ja turvalisema kasutamisega. Kõige olulisema tegevusena viis EU Kids Online 2010. aastal 25 riigis läbi intervjuud, mille käigus küsitleti kodudes 25000 internetikasutajat vanuses 9-16 aastat ja nende vanemaid, kasutades stratifitseeritud juhuvalimit ja isetäidetavaid küsitluslehti delikaatsete küsimustega. Võrgustik, mis ühendab teadlasi ja sidusrühmi 33 riigist Euroopas ja väljaspool seda, jätkab kogutud andmete analüüsimist ja ajakohastamist, et poliitikakujundajaid oma töö tulemustest teavitada. Kõik aruanded, tulemused ja tehniline teave ning täielik ülevaade iga riigi partneritest on kättesaadav veebisaidilt www.eukidsonline.net. 
1) üksiku kasutaja tasand peamiselt koduse keskkonna mikrosüsteemis;

2) sotsiaalse vahenduse tasand, mis on seotud peamiselt kodu, kooli ja samaväärsete kultuuridega;

3) riiklik tasand, kus riik on analüüsiühik ja kus kujundavateks teguriteks on sellised makrosüsteemi nähtused nagu sotsiaalmajanduslik kihistumine, reeglite süsteemid ja kultuurilised väärtushinnangud.

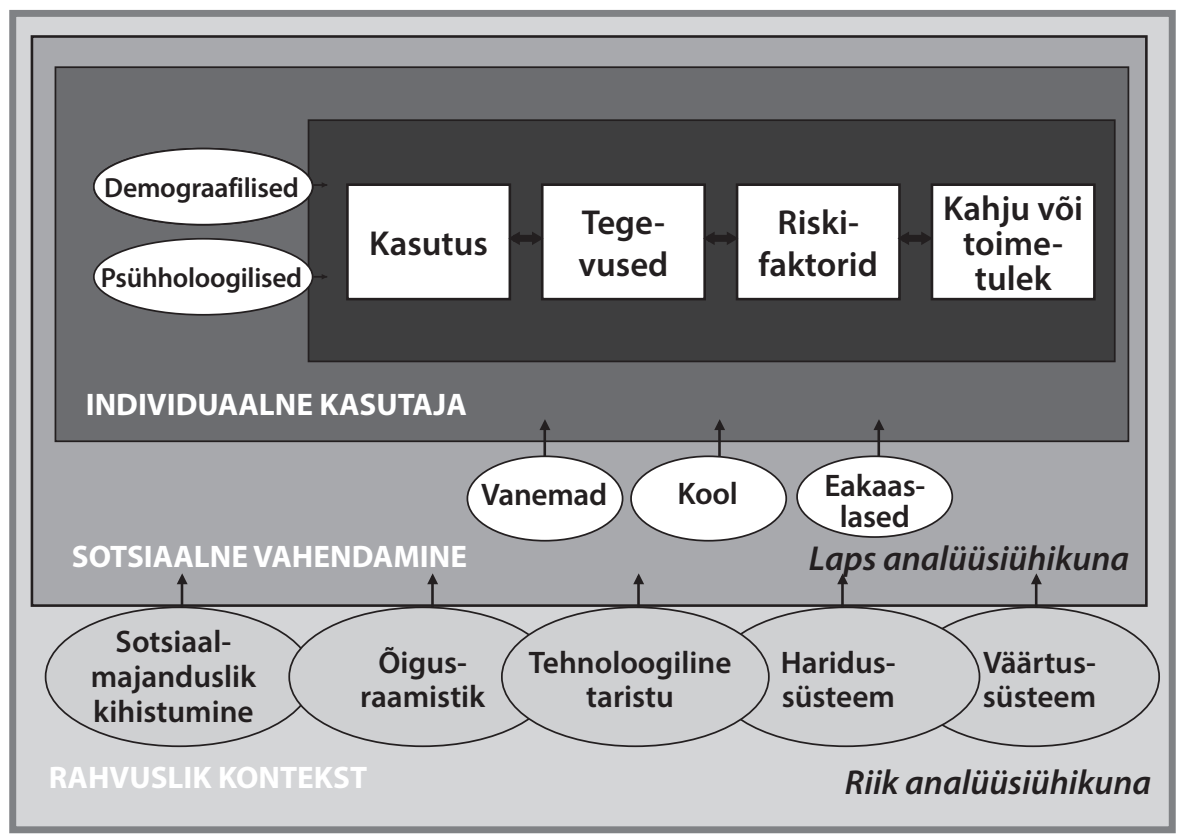

Joonis 3. EU Kids Online'i uuringus kasutatud mudel (Hasebrink, Görzig, Haddon, Kalmus, \& Livingstone, 2011)

Eelnimetatud põhjustel keskenduti EU Kids Online'i uuringus laste igapäevasele internetikasutusele (sellele, kus, kuidas ja kui kaua nad veebis viibivad), millele järgnesid aruanded nende veebitegevuse kohta, et hinnata riskifaktoreid ja võimalikke tagajärgi ebameeldivate tegurite kujul, nagu lapsed ise neid määratlesid, või seda, kuidas tulevad kasutajad toime potentsiaalselt ohtlike kogemustega. Riskifaktorid selgitati välja pärast olemasolevate andmete läbitöötamist (Livingstone \& Haddon, 2009) ja teabe saamist teemade kohta, mis on äratanud politsei huvi (Byron, 2008; Internet Safety Technical Task Force, 2008). Neile lisandusid ka laste enda arvamused selle kohta, mis oli nende arvates häiriv (Smahel \& Wright, 2014). Laste kogemuste eristamisel lähtuti peamiselt sellistest demograafilistest näitajatest nagu vanus, sugu ja sotsiaalmajanduslik staatus, aga ka psühholoogilistest teguritest, näiteks emotsionaalsed probleemid, enesekindlus ja 
riskijulgus. Sotsiaalseid tegureid, eelkõige vanemate, õpetajate ja eakaaslaste vahendavat rolli, samuti suurt hulka riikliku tasandi tegureid, võrreldi ja eristati pigem makrotasandit käsitlevate uurimistulemuste alusel.

Kuigi ühte, laialdaselt aktsepteeritud ja usaldusväärset teooriat laste internetikasutuse kohta ei ole olemas (Livingstone et al., 2012), aitab ökoloogilise käsitlusviisi rakendamine laste veebikasutuse uurimisel süstematiseerida suurt andmekogumit, mis koosneb peaaegu tuhandest muutujast, mida kasutatakse teoreetiliste järelduste tegemiseks. Sellel mudelil põhinevad paljud üldistavad järeldused, mille põhjal luuakse üldine ohte ja turvalisust määrav mudel, mida on kokkuvõtlikult kirjeldatud allpool.

Empiiriline analüüs annab üksikisiku tasandil ehk mikrosüsteemi tasandil, nagu bioökoloogiline raamistik seda määratleb, tulemuseks lastevahelised sarnasused ja erinevused, viidates sellele, et lapsepõlv ei ole homogeenne kategooria ning internet sellisel kujul, nagu noored on selle omaks võtnud, on omaette üksus või kogemus. Noorte internetikasutajate tüpoloogia järgi, mis on koostatud kasutuse, tegevuste ja riskide kobaranalüüsi põhjal, eristatakse kuut kasutajatüüpi: tagasihoidlikud kasutajad, riskialtid avastajad, kogenud veebisuhtlejad, noored veebisuhtlejad, intensiivsed mängijad ja väikse riskiga algajad. Tabelis 1 on esitatud ülevaade iga tüübi peamistest tunnusjoontest, mis on liigitatud ohtude ja kahjude järgi, võimaldades teha üldistavaid järeldusi (Hasebrink et al., 2011).

Tabel 1. Riskide ja kahjude põhjal ilmnenud kuus kasutajatüüpi (Livingstone et al., 2012)

\begin{tabular}{|c|c|c|}
\hline & Väike risk & Suur risk \\
\hline Väiksem kahju saamise risk & $\begin{array}{l}\text { Tagasihoidlikud } \\
\text { kasutajad }\end{array}$ & Riskialtid avastajad \\
\hline Vanus & Nooremad (12,7aastased) & Vanemad (13,5aastased) \\
\hline Tüdrukute osakaal & $48 \%$ & $\begin{array}{l}\text { Rohkem poisse ( } 38 \% \\
\text { tüdrukuid) }\end{array}$ \\
\hline $\begin{array}{r}\text { Kasutusaeg (internetis veedetud } \\
\text { minuteid päevas) }\end{array}$ & Lühike (71) & Pikk (118) \\
\hline Tegevused internetis (17st) & Keskmiselt $(7,7)$ & Väga palju $(13,2)$ \\
\hline Ohtlikud tegevused internetis (5st) & Vähe $(0,7)$ & Väga palju $(2,1)$ \\
\hline Interneti kasutamise oskused (8st) & Keskmised $(3,9)$ & Üsna head $(5,8)$ \\
\hline \multirow[t]{2}{*}{$\begin{array}{r}\text { Piirav vanemlik vahendamine } \\
\text { (lapse arvamuse kohaselt) }\end{array}$} & Keskmine (87\%) & Vähene (69\%) \\
\hline & & $\begin{array}{l}\text { Kogenud } \\
\text { veebisuhtlejad }\end{array}$ \\
\hline
\end{tabular}




\begin{tabular}{|c|c|c|}
\hline & Väike risk & Suur risk \\
\hline Vanus & & Vanimad $(14,1$ aastased $)$ \\
\hline Tüdrukute osakaal & & Rohkem tüdrukuid (67\%) \\
\hline $\begin{array}{r}\text { Kasutusaeg (internetis veedetud } \\
\text { minuteid päevas) }\end{array}$ & & Pikk (108) \\
\hline Tegevused internetis (17st) & & Palju $(9,6)$ \\
\hline Interneti kasutamise oskused (8st) & & Üsna head $(5,4)$ \\
\hline Ohtlikud tegevused internetis (5st) & & Palju $(1,5)$ \\
\hline $\begin{array}{r}\text { Piirav vanemlik vahendamine } \\
\text { (lapse arvamuse kohaselt) }\end{array}$ & & Keskmine (81\%) \\
\hline Keskmine kahju saamise risk & Noored veebisuhtlejad & Intensiivsed mängijad \\
\hline Vanus & Nooremad (12,7aastased) & Vanemad (13,6aastased) \\
\hline Tüdrukute osakaal & $55 \%$ & $\begin{array}{l}\text { Rohkem poisse }(37 \% \\
\text { tüdrukuid) }\end{array}$ \\
\hline $\begin{array}{r}\text { Kasutusaeg (internetis veedetud } \\
\text { minuteid päevas) }\end{array}$ & Lühike (72) & Väga pikk (180) \\
\hline Tegevused internetis (17st) & Vähe $(5,2)$ & Palju $(9,8)$ \\
\hline Ohtlikud tegevused internetis (5st) & Keskmiselt $(1,0)$ & Palju $(1,6)$ \\
\hline Interneti kasutamise oskused (8st) & Keskmised $(3,8)$ & Üsna head $(5,4)$ \\
\hline $\begin{array}{r}\text { Piirav vanemlik vahendamine } \\
\text { (lapse arvamuse kohaselt) }\end{array}$ & Keskmine (87\%) & Üsna harv (76\%) \\
\hline Suurem kahju saamise risk & Väikse riskiga algajad & \\
\hline Vanus & $\begin{array}{l}\text { Kõige nooremad } \\
(11,1 \text { aastased })\end{array}$ & \\
\hline Tüdrukute osakaal & $50 \%$ & \\
\hline $\begin{array}{r}\text { Kasutusaeg (internetis veedetud } \\
\text { minuteid päevas) }\end{array}$ & Väga lühike (50) & \\
\hline Tegevused internetis (17st) & Väga vähe (3) & \\
\hline Ohtlikud tegevused internetis (5st) & Väga vähe $(0,3)$ & \\
\hline Interneti kasutamise oskused (8st) & Väga vähesed $(1,7)$ & \\
\hline $\begin{array}{r}\text { Piirav vanemlik vahendamine } \\
\text { (lapse arvamuse kohaselt) }\end{array}$ & Sagedane (96\%) & \\
\hline
\end{tabular}


Ökoloogilisest vaatenurgast lähtudes võib selle analüüsi põhjal teha individuaalse kasutaja tasandil mõned olulised järeldused. Esiteks on näha, et vanus on üks peamisi eristavaid tegureid, mis kinnitab internetikasutuse kohta kehtivate arenguväljavaadete tähtsust. Sugu on vähem oluline faktor, välja arvatud juba varem hästi teada olnud erinevused internetitegevustes. Teiseks leidis kinnitust hüpotees („rohkem on rohkem”), et mida enam on internetikasutust ja -tegevusi, seda rohkem on võimalusi ja riske. Lapsed, kes kasutavad internetti regulaarselt ja intensiivselt, omandavad rohkem oskusi, kasutavad suuremat hulka veebis pakutavaid võimalusi ja näib, et puutuvad kokku ka suurema hulga riskidega. Kuna oluline on teha vahet riski ja kahju vahel, on kolmas tähtis järeldus see, et kahju saamise risk ei vii ilmtingimata tegeliku kahju saamiseni. Kahju saamise risk on tegelikult väike ja üllataval kombel saavad rohkem kahjustada just need lapsed, kelle internetikasutus ja risk on väiksemad. Seega on olulisem keskenduda haavatavate rühmade toimetulekule ja kahjust taastumisele, mitte niivõrd riskidele.

\section{Makrotasandi analüüs}

Kui lähtuda arenguuuringutest üldisemalt, siis kõige edukamaks on osutunud individuaalse kasutaja mikrosüsteemi tasandi analüüsid, mis on viidanud kõige selgematele seostele kasutuse, oskuste ja riskide vahel. Need on andnud teadlastele hulgaliselt materjali, mille põhjal uurida riskimustreid, vahendamise rolli ja konkreetsete populatsioonide haavatavust, mida iseloomustavad olulised demograafilised ja psühholoogilised muutujad.

Sotsiaalse vahendamise teema on EU Kids Online'i uuringus samuti tugevalt esindatud vanemate ja lastega tehtud intervjuude näol. See annab võimaluse vanemate ja laste versioonide võrdlemiseks uuringu põhiküsimuste alusel. Lastelt saadud andmed, mis hõlmavad juurdepääsu, kasutust ja tegevusi koolis ning eakaaslaste kui toetajate rolli ning usaldusväärse toe saamist muudelt välistelt allikatelt, avardavad sotsiaalse vahendamise analüüsi võimalusi.

Riikidevaheline tasand pakub märkimisväärselt suurt võimalust koguda uusi teadmisi, laiendades ökoloogilise käsitlusviisi potentsiaali nii, et see hõlmaks kultuurilisi ja rahvuslikke tegureid. Samas on riikidevahelised analüüsid osutunud mõnes mõttes keerulisemaks ja hoolimata usutavatest hüpoteesidest kultuuriliste ja rahvuslike eripärade kohta on sel tasandil kogutud andmed keerulist laadi ja pakuvad vähem võimalusi lihtsaks tõlgendamiseks (Lobe, Livingstone, Ólafsson, \& Vodeb, 2011). 
Makrosüsteemi analüüsi väljatöötamisel prooviti EU Kids Online’i uuringus kasutada riikide erinevust arvestavat tüpoloogiat. Kuna iga riik avaldab endale iseloomulikud jooned, kasutusmustrid, võimalused ja riskid, siis loodi Euroopa tasandil ilmnevate erinevuste näitamiseks neli laiemat kategooriat ehk teoreetilist tüüpi, mis sisaldasid kasutuse ja riski paare: „väiksem kasutus, väiksem risk”, „väiksem kasutus, mõningane risk”, „suurem kasutus, mõningane risk” ja „suurem kasutus, suurem risk”. Seega eeldati, et rikkamates Põhjamaades, Ühendkuningriigis ja Hollandis, kus internetikasutuse tase on kõrge, on ka riskitase kõrgem: üldise suundumuse kohaselt on SKT-l inimese kohta positiivne ja märkimisväärne mõju riskitasemele riigis (Lobe et al., 2011). Usaldusväärsete ja võrreldavate andmeteta tehnoloogilise taristu, õigusraamistiku ja kultuuri kohta on makrotasandi võrdlevat analüüsi siiski keeruline teha. Lisaks selgus, et erinevused riikide sees olid oluliselt suuremad kui riikide vahel, mis muutis üldistuste tegemise veelgi keerulisemaks.

Helsper ja tema kolleegid (2013) töötasid välja täiustatud klassifikatsiooni, ajakohastades ja süvendades arusaamu 25 riigi vahelistest erinevustest. Uues klassifikatsioonis arvestatakse eri tüüpi võimalusi, riske ja kahju, mida eri riikide lapsed kogevad internetis, samuti seda, kuidas eri riikide lapsevanemad vahendavad või piiravad laste internetikasutust. Analüüsi tulemusena koostati riikide tasandil kasutuse, riskide ja vahendamise suhteid iseloomustavad neli rühma (joonis 4):

- toetatud riskialtid avastajad;

- pooleldi toetatud riskialtid mängijad;

- piirangutega kaitstud;

- kaitseta internetisuhtlejad (ibid.).

O’Neill (2014) on lisanud rahvusliku tasandi keskkonnateguritele veel ühe dimensiooni, et uurida poliitilist konteksti igas riigis ja seda, milliseid meetmeid võtavad eri rühmadesse kuuluvad riigid noorte internetiturvalisuse tagamiseks. Selles analüüsis püstitatakse küsimus, kas mõni riiklik või piirkondlik poliitiline raamistik või meede vähendab riske, suurendab internetipõhiseid võimalusi või mõjutab vanemliku vahendamise iseloomu või ulatust. Tuginedes Euroopa Komisjoni tellimusel korraldatud lisauuringule (Idate \& Technopolis, 2014), kasutatakse selles analüüsis iga riigi ühiskondlikku raamistikku iseloomustavaid näitajaid (riigivalitsemise kord, tegevussuundade ulatus, õiguslik ja regulatiivne raamistik ning teadusuuringute, seire ja hindamise kasutamine poliitiliste otsuste tegemisel), samuti tegelikult rakendatavat poliitikat, et uurida täpsemalt mis tahes ilmseid erinevusi riikide vahel. 


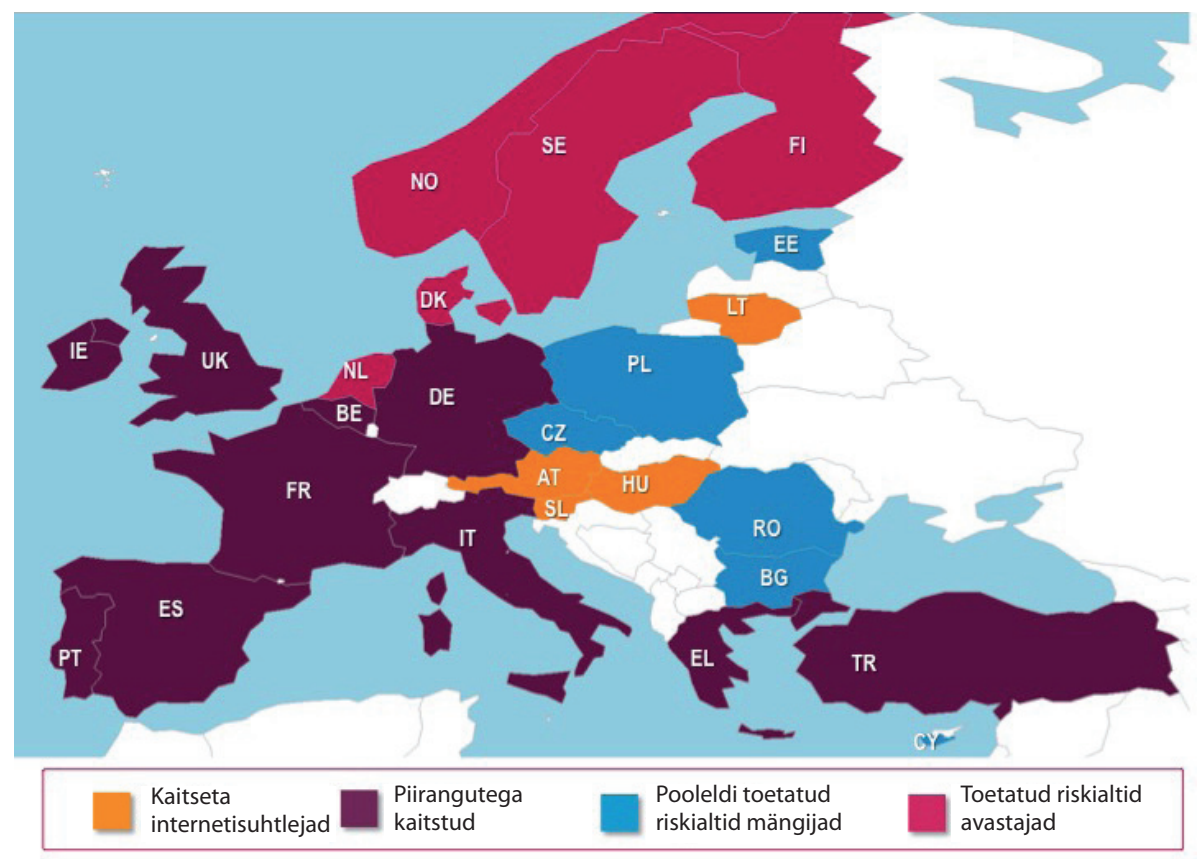

Joonis 4. Klassifikatsioon internetist tulenevate võimaluste, riskide, kahju ja vanemliku vahendamise alusel (Helsper et al., 2013)

Selle analüüsi põhjal võib teha järgmised järeldused (O’Neill, 2014).

- Riigid, mis kuuluvad rühma „piirangutega kaitstud”, on teinud rohkem selleks, et luua struktuurid ning jõustada õiguslikud ja regulatiivsed raamistikud turvalisuse tagamiseks internetis, kuigi sellega takistatakse veebivõimaluste edendamist.

- Riikides, mis kuuluvad rühma „toetatud riskialtid avastajad”, on peale turvalisema interneti keskuste tagatud ka avaliku sektori suurem osalus. Neis riikides on asjakohased eelarvelised eraldised ja poliitiliste otsuste hindamine rohkem levinud, internetilevik laialdasem ja digitaalsed oskused nii lapsevanemate kui ka laste hulgas paremal tasemel ning ennetav vahendamine sagedasem.

- Riikides, mis kuuluvad rühmadesse „pooleldi toetatud riskialtid mängijad” ja „kaitseta internetisuhtlejad”, panustatakse erinevalt teistest rühmadest turvalisusse suhteliselt ebaühtlaselt. Need riigid investeerivad kõnealusesse valdkonda märgatavalt vähem, avaliku sektori kaasamine on tunduvalt väiksem ning halvemini koordineeritud.

Huvitaval kombel näitas kasutamise ja riskimudelite analüüs mikroja makrosüsteemi tasandil, et nii üksikisikute jaoks kui ka poliitilises ja õiguslikus plaanis ei ole olemas ühtset malli, mis võimaldaks seletada 
kasutajate kogemust või muuta meediakeskkonda turvalisemaks. Samas on kasutusele võetud suur hulk mitmesuguseid meetmeid, mis annavad nii positiivseid kui ka võimalikke negatiivseid tulemusi ning mis on kohandatud eri arengustaadiumitele ja kontekstile, milles lapsed ja noored kasvavad, ópivad ja suhtlevad. Samamoodi rakendatakse ka riiklikul tasandil mitmesuguseid meetodeid, mis mõjutavad meediakeskkonna kvaliteeti erineva intensiivsusega.

Kui rääkida meediakasutusest või internetiturvalisusest, siis on lähtekohad erinevad: mõned kasutajad - ja riigid - saavad rohkem toetust, on paremini varustatud, omavad paremaid oskusi ja saavad rohkem hüvesid. Mõnes riigis on nii avaliku kui ka erasektori poliitilise sekkumise kogemus üsna pikaajaline. Seevastu teistes Euroopa piirkondades on internetiturvalisust käsitlevate tegevussuundade väljatöötamine ja strateegiate rakendamine alles hiljuti päevakorda tõusnud. Olulisi soovitusi edasiste otsuste tegemisel saavad seetõttu anda vaid need Euroopa piirkonnad, kus on kõige kauem tegeletud internetti ja noori puudutavate poliitiliste küsimustega ning püütud leida tasakaalu konkureerivate nõudmiste vahel: edendada noorte inimeste võimalusi ja kaitsta neid samal ajal kõige enam survestavate riskide eest.

\section{Kokkuvõte}

Sageli kritiseeritakse ökoloogilist vaatenurka lapse arengule selle laialivalguvuse tõttu, samuti seepärast, et sellega kaasnevad raskused testida või hinnata kõiki komponente empiiriliselt. Ökoloogilise käsitlusviisi korral on "kõigel tähtsus” ja seetõttu on keeruline koostada selgitavat mudelit või luua ühest selgitavat raamistikku või ennustada tulemusi (Downes, 2014). Nagu eespool väidetud, tulevad siiski esile ökoloogilise vaatenurga mitmed kasulikud omadused, mis kaaluvad üles selle puudused selgitava raamistikuna ning avalduvad selle potentsiaalis tõlgendava raamistikuna. See keskendub pigem protsessile kui esemetele ning muudab subjektid arenevateks ja õppimisele orienteeritud olenditeks. Ökoloogiline vaatenurk on ühtlasi raamistik, mis innustab ühendama punkte mikrosüsteemi nähtuste ja makrosüsteemi tasandi kultuurikonteksti vahel. See heidab kõrvale tahtevabadust eitava vaieldamatult tehnoloogilise vaatenurga ja toetab tehnoloogia kujundamist ühiskonnas, tunnistades samas, et ootusi mõjutavad vastuvõetud ja struktureeritud keskkonnatingimused. Selle kaudu arendatakse edasi pikaajalist ja ajalooliselt välja kujunenud seisukohta, mis kipub mitmeid piirkondi hõlmavate laiaulatuslike uuringute puhul ununema. 
Rakendades analüüsi ja mõningaid olulisimaid EU Kids Online’i uuringu tulemusi, mis on saadud ökoloogilist vaatenurka kasutades, on Livingstone (2013) teinud kokkuvõtte mitmest üldisest teemast, mis aitavad kaasa noorte veebitehnoloogia kasutamise mõistmisele ökoloogilisest vaatepunktist. Need tulemused võib kokku võtta viie peamise punktina, mis panevad aluse edasistele uuringutele ja pikemaajalistele hinnangutele, mis puudutavad uue meediatehnoloogia kasutamist hariduskeskkonnas (ibid.).

1. Lapsed on olendid, kes elavad maailmas, mis ei ole enamalt jaolt nende enda loodud. Lapsed võivad olla uue meediatehnoloogia vastuvõtjate hulgas küll esimeste seas ja omandada uute tehnoloogiliste vahendite valdamise oskused näilise kergusega, kuid vale oleks arvata, et nad on ühelt poolt täielikud meediataibud ja teiselt poolt lihtsalt väliste meediajõudude ohvrid. Uuringud on näidanud, et lapsed etendavad mitmesuguseid rolle meediakeskkonnas, mida nad kasutavad: nad tegutsevad sotsiaalvõrgustikes kui vastuvõtjad, osalejad ja tegutsejad, olles mõjutatud oma varasematest kogemustest ja kodusest keskkonnast. Internet pakub lõputult hüvesid ja kätkeb hulgaliselt riske, mis võivad mitmekordistuda olenevalt sotsiaalsest keskkonnast, kus neid kogetakse. Seetõttu peaks hariduskorraldus lähtuma ühiskonnas toimuvast ning suhtuma vastuvõtlikult võimalustesse, oskustesse, kogemustesse ja piirangutesse, millega lapsed kokku puutuvad.

2. Interneti kasutamine pakub lastele võimalusi ja seab nad ohtu ning need asjad on omavahel seotud. Meediatehnoloogia, mida lapsed kasutavad, ei ole iseenesest ei hea ega halb. See pakub hüvesid ja võimalusi ning tekitab ka kahjusid ja riske - nagu tõendid näitavad, langevad need kaks sageli kokku. Seetõttu peavad haridusmetoodikud peale riski ohjamise püüdma ka tagada, et nad ei vähendaks tahtmatult laste võimalusi. Samamoodi on ekslik propageerida internetipõhiseid võimalusi, ilma et mõeldaks sellega kaasnevatele riskidele. Ka ei tohi riskide vähendamiseks rakendatavaid piiranguid kasutusele võtta ilma, et kaalutaks nende mõju laste internetipõhistele võimalustele.

3. Risk viitab kahju tekkimise statistilisele tõenäosusele (mitte paratamatusele) ja see ei ole ilmtingimata halb. Risk on olnud alati domineerivaks teemaks, kui arutluse all on uue meediatehnoloogia ja interneti roll laste elus, eelkõige hariduskeskkonnas. Koolid on riskide suhtes pigem ülitundlikud ja seetõttu püüdlevad nad selle poole, et soetatava tehnoloogiaga kaasneks võimalikult vähe riske. Samas näitas EU Kids Online’i uuring, et riskid, mis lapsi häirisid, ei ole alati need, mis täiskasvanutele muret teevad. Võimalik, et püüdes nii kodus kui ka koolis lapsi kaitsta, 
tegeletakse valede riskidega või jääb laste tegelikult kogetav kahju hoopiski tähelepanuta. Uuring viitab sellele, et ülioluline on kuulata, mida peavad noored ise kõige häirivamateks riskideks (nt küberkiusamine), ja keskenduda vähem mõningatele sensatsioonimaigulistele riskidele, mida tuleb harva ette (nt võõrastega suhtlemise ja seksuaalse ärakasutamise oht). Tunnistada tuleks ka seda, et koos kasutajate enda loodud sisu suurenemisega on noored ka ise riski ja kahju tekitajad ning laste enda tegevusel tuleb silma peal hoida.

4. Laste veebikogemust kujundavad nii isiklikud, kodused kui ka kultuuridevahelised tegurid. EU Kids Online'i uuringuga kogutud andmed moodustavad rikkaliku allika, mis võimaldab uurida mitmesuguseid isiklikul, ühiskondlikul ja kultuuridevahelisel tasandil toimivaid tegureid. Uuringu põhjal võib järeldada, et vanus on peamine laste kogemusi eristav tegur. Lapse psühholoogilised raskused või riskialdis olek on mõjukuselt järgmine. Vanemate internetikasutus ja selle valdamine on samuti olulised ning neil näib olevat suurem mõju kui sotsiaalmajanduslikul staatusel. Aktiivne lapsevanemlik vahendamine üleliia piirava tegutsemise asemel aitab samuti parandada lapse internetikogemust. Analüüsi võrdlev iseloom võimaldab veelgi põhjalikumalt uurida kultuuridevahelisi erinevusi ja hinnata, kui palju on lastel kasu sellest, et nad on sündinud rikkamasse riiki, kus tehakse suuremaid investeeringuid koolis kasutatavasse tehnoloogiasse. Riikide võrdlemine jääb sellest hoolimata keeruliseks ülesandeks, mis nõuab lisaandmete kogumist ja üksikasjalikku analüüsi.

5. Vajatakse paljude sidusrühmade sagedasemaid ja tõhusamaid sekkumisi, nagu on öelnud Euroopa Komisjoni endine asepresident Neelie Kroes, „et muuta internet laste jaoks paremaks paigaks". EU Kids Online'i uuringus leitakse, et poliitika kujundamine muutub tõhusaks vaid siis, kui see lähtub tõendatud andmetest. Siiani on lähenetud eeskirjadele ja hariduslikele sekkumistele ebapiisava informeerituse pinnalt, omamata piisavaid andmeid noorte tegelike kogemuste kohta tehnoloogia kasutamisel. Propageerides uue meediatehnoloogia hüvesid noortele, on väga tähtis, et esindatud oleksid kõik meediakeskkonna olulised elemendid, sealhulgas tööstus, mille ülesanne on täiustada veebiteenuste disaini (nt sotsiaalvõrgustikud) ja nende turvanõudeid (nt teavitamisvahendid, vanemliku kontrolli vahendid), ning õpetajad ja teised lastega töötavad inimesed, kes saavad noorte teadlikkust tõhusamalt suurendada ning pakkuda neile tuge ja suuremat turvalisust. Niimoodi on haridusel unikaalne positsioon, millelt ulatub iga lapseni, et edastada neile hädavajalikke 
oskusi ja toetada õppimiskogemust, parandades seeläbi laste ja noorte toimetulekut ning soodustades pikaajalist digitaalset kodakondsust.

Kokkuvõtteks võib öelda, et nagu siinses uurimuses juba väidetud, aitab ökoloogiline lähenemine laste internetikogemuse uurimisele kirjeldada meediakeskkonda kui keerulise vastastikuse mõjutamise süsteemi tehnoloogia ja ühiskonna vahel, kus kommunikatsiooniviisid ja vahendatud vastastikune mõjutamine kujundavad oluliselt inimkäitumist ja ühiskondlikku elu. Selline vaatenurk on mõningate põletavate probleemidega tegelemisel väga vajalik, kui kõne all on teadusuuringutel põhinev poliitika kujundamine, mis on seotud interneti haldamise, reguleerimise ja noorte kaitsmisega internetikeskkonnas.

\section{Kasutatud kirjandus}

American Academy of Pediatrics (2013). Children, adolescents, and the media. Pediatrics, 132(5), 958-961. Retrieved from http://pediatrics.aappublications.org/content/132/5/958.full.pdf+html. doi: http://dx.doi.org/10.1542/peds.2013-2656

Atkin, D. J. (2001). Home ecology and children's television viewing in the new media environment. In J. Bryant \& J. A. Bryant (Eds.), Television and the American family (2nd ed., pp. 49-74). London: Routledge.

Atkin, D. J., Greenberg, B. S., \& Baldwin, T. F. (1991). The home ecology of children's televison viewing: Parental mediation and the new video environment. Journal of Communication, 41(3), 40-52.

doi: http://dx.doi.org/10.1111/j.1460-2466.1991.tb02322.x

Bates, T. (1984). Broadcasting in education: An evaluation. London: Constable.

Bronfenbrenner, U. (1975). Influences on human development (2nd Rev. ed.). Hinsdale, IL: Holt McDougal.

Bronfenbrenner, U. (1979). The ecology of human development. Cambridge, MA: Harvard University Press.

Bronfenbrenner, U. (2005). Growing chaos in the lives of children, youth, and families: How can we turn it around? In U. Bronfenbrenner (Ed.), Making human beings human: Bioecological perspectives on human development (pp. 185-197). Thousand Oaks, CA: Sage.

Bronfenbrenner, U., \& Ceci, S. J. (1994). Nature-nurture reconceptualized in developmental perspective: A bio-ecological model. Psychological Review, 101(4), 568586. doi: http://dx.doi.org/10.1037/0033-295X.101.4.568

Byron, T. (2008). Safer children in a digital world: The report of the Byron Review. London: DCSF. Retrieved from www.dcsf.gov.uk/byronreview.

Cantril, H., \& Allport, G. W. (1935). The psychology of radio. New York, NY: Harper \& Brothers.

Carey, J. W. (1981). McLuhan and Mumford: The roots of modern media analysis. Journal of Communication, 31(3), 162-178.

doi: http://dx.doi.org/10.1111/j.1460-2466.1981.tb00440.x 
Downes, P. (2014). Conceptual framework and agenda: Beyond Bronfenbrenner $(1979,1995)$ to interrogation of blocked systems via structural indicators. In Access to education in Europe (pp. 29-48). Dordrecht: Springer Netherlands. doi: http://dx.doi.org/10.1007/978-94-017-8795-6_3

Gillespie, A. (2008). Child exploitation and communication technologies. Lyme Regis, Dorset: Russell House Publishing.

Glucksmann, A., \& Bennett, S. (1971). Violence on the screen: A report on research into the effects on young people of scenes of violence in films and television. London: British Film Institute (Education Department).

Grosswiler, P. (2006). The transformation of Carey on McLuhan: Admiration, rejection and redemption. Explorations in Media Ecology, 5(2), 137-148. doi: http://dx.doi.org/10.1386/eme.5.2.137_1

Halpern, R., \& Figueiras, A. C. M. (2004). Environmental influences on child mental health. Jornal de Pediatria, 80(2), 104-110. doi: http://dx.doi.org/10.1590/S0021-75572004000300013

Hasebrink, U., Görzig, A., Haddon, L., Kalmus, V., \& Livingstone, S. (2011). Patterns of risk and safety online. In-depth analyses from the EU Kids Online survey of 9to 16-year-olds and their parents in 25 countries. LSE, London: EU Kids Online. Retrieved from http://eprints.lse.ac.uk/39356/.

Hasebrink, U., Livingstone, S., Haddon, L., \& Ólafsson, K. (2009). Comparing children's online opportunities and risks across Europe: Cross-national comparisons for EU Kids Online. LSE, London: EU Kids Online. Retrieved from http://eprints.lse.ac.uk/21656/.

Heins, M. (2008). Not in front of the children: "Indecency," censorship, and the innocence of youth (2nd Rev. ed.). New Brunswick, NJ: Rutgers University Press.

Helsper, E. J., Kalmus, V., Hasebrink, U., Ságvári, B., \& Haan, J. D. (2013). Country classification: Opportunities, risks, harm and parental mediation. LSE, London: EU Kids Online. Retrieved from http://eprints.lse.ac.uk/52023/.

Idate, \& Technopolis (2014). Benchmarking of safer internet policies in member states and policy indicators: Final report. Retrieved from http://www.technopolis-group. $\mathrm{com} /$ ?report=benchmarking-safer-internet-policies-in-the-eu-member-states.

Internet Safety Technical Task Force (2008). Enhancing child safety and online technologies: Final report of the Internet Safety Technical Task Force to the multi-state working group on social networking of state attorneys general of the United States. Boston, MA: Berkman Center for Internet \& Society at Harvard University.

Johnson, G. M., \& Puplampu, K. P. (2008). Internet use during childhood and the ecological techno-subsystem. Canadian Journal of Learning and Technology / La Revue Canadienne de L'apprentissage et de La Technologie, 34(1). Retrieved from http://www.cjlt.ca/index.php/cjlt/article/viewArticle/172.

Jordan, A. (2004). The role of media in children's development: An ecological perspective. Journal of Developmental \& Behavioral Pediatrics, 25(3), 196-206. doi: http://dx.doi.org/10.1097/00004703-200406000-00009

Jowett, G. S., Jarvie, I. C., \& Fuller, K. H. (1996). Children and the movies: Media influence and the Payne Fund controversy. Cambridge: Cambridge University Press.

Livingstone, S. (2013). „Knowledge enhancement”: The risks and opportunities of evidence-based policy. In B. O’Neill, E. Staksrud, \& S. Mclaughlin (Eds.), Towards a 
better Internet for children? Policy pillars, players and paradoxes. Goteborg: Nordicom. Retrieved from eprints.lse.ac.uk/59673/.

Livingstone, S., \& Haddon, L. (2009). EU Kids Online: Final report 2009. LSE, London: EU Kids Online. Retrieved from http://eprints.lse.ac.uk/24372/.

Livingstone, S., Haddon, L., \& Görzig, A. (2012). Children, risk and safety on the Internet: Research and policy challenges in comparative perspective. Bristol: Policy Press. doi: http://dx.doi.org/10.1332/policypress/9781847428837.001.0001

Lobe, B., Livingstone, S., Ólafsson, K., \& Vodeb, H. (2011). Cross-national comparison of risks and safety on the Internet: Initial analysis from the EU Kids Online survey of European children. LSE, London: EU Kids Online. Retrieved from http://eprints.lse.ac.uk/39608/.

Moody, K. (1999). The children of Telstar: Early experiments in school television production. New York, NY: Vantage Press.

O'Neill, B. (2014). Policy influences and country clusters: A comparative analysis of Internet safety policy implementation. LSE, London: EU Kids Online. Retrieved from http://eprints.lse.ac.uk/57831/.

Palfrey, J., \& Gasser, U. (2010). Born digital: Understanding the first generation of digital natives. New York, NY: Basic Books.

Postman, N. (2000). The humanism of media ecology. Proceedings of the Media Ecology Association 1, 10-16. Retrieved from http://w.media-ecology.org/publications/MEA_proceedings/v1/postman01.pdf.

Prensky, M. (2001). Digital natives, digital immigrants. On the Horizon, 9(5). Retrieved from http://www.marcprensky.com/writing/Prensky\%20-\%20Digital\%20Natives,\%20Digital\%20Immigrants\%20-\%20Part1.pdf. doi: http://dx.doi.org/10.1108/10748120110424816

Resnick, P., \& Miller, J. (1996). PICS: Internet access controls without censorship. Communications of the ACM, 39(10), 87-93. doi: http://dx.doi.org/10.1145/236156.236175

Ross, S. M. (2009). Postman, media ecology, and education: From Teaching as a Subversive Activity through Amusing Ourselves to Death to Technopoly. Review of Communication, 9(2), 146-156. doi: http://dx.doi.org/10.1080/15358590802326435

Schramm, W., Lyle, J., \& Parker, E. B. (1961). Television in the lives of our children. Palo Alto, CA: Stanford University Press.

Smahel, D., \& Wright, M. F. (2014). The meaning of online problematic situations for children. Results of qualitative cross-cultural investigation in nine European countries. LSE, London: EU Kids Online. Retrieved from http://eprints.lse.ac.uk/56972/.

Spitzer, M. (2012). Digital dementia: How we and our children are doing to our minds. Munich: Droemer.

Strate, L. (2004). A media ecology review. Communication Research Trends, 23(2), 3.

Surgeon General's Scientific Advisory Committee on Television and Social Behavior. (1972). Television and growing up: The impact of televised violence. Report to the Surgeon General, United States Public Health Service. Washington, D.C.: National Institute of Mental Health. 